\title{
Three Dimensional Norm-Based Knowledge Management for Knowledge Intensive Business Service Organizations: An Organizational Semiotics Perspective
}

\author{
Yu-Chun Pan and Chekfoung Tan
}

\begin{abstract}
The utilization of knowledge enables knowledge intensive business service (KIBS) organizations, such as law firms, to perform and deliver value to their customers. Organizational semiotics views norms as knowledge that are developed through practical experience of human agents in organizations. Building on organizational semiotics and knowledge management, this paper proposes a three dimensional norm-based knowledge management (3DNKM) framework for legal sector in the UK. Abductive reasoning is adopted for guiding the research process in this paper. The three identified contextual dimensions of knowledge include customer, practice area and lawyer. For each dimension, there are informal, formal and technical norms establishing context-based knowledge. The proposed framework provides a way for KIBS organizations to manage the intertwined norms from the three dimensions and various levels.
\end{abstract}

Index Terms-Knowledge intensive business service, knowledge management, legal, organizational semiotics.

\section{INTRODUCTION}

Organizations create and deliver value to customers through a variety of ways, such as offering tangible goods or intangible services. In the modern world, more and more organizations deliver intangible services to their customers. Organizations that offer services often utilize knowledge to create value and contribute to the knowledge economy [1]. Knowledge intensive business services (KIBS) organizations accumulate, create and disseminate supplier's specialist knowledge to deliver customized services or solutions to satisfy customer needs [2], [3]. The importance of knowledge management has been recognized in KIBS industries such as health care sector [4] and legal sector [5]. In recent years, legal services, as a type of KIBS, have been under pressure to improve their operations model to meet modern world customers' requirements at a lower cost via adopting the techniques and technologies already widely used in other industries [6]-[10]. In the UK, since the recession and the advent of the Legal Service Act 2007, non-lawyers have been allowed to enter the legal market, which consequently has increased the level of competition [11]. Legal practitioners

Manuscript received June 26, 2015; revised October 27, 2015. This work was supported in part by a grant from Knowledge Transfer Partnership (KTP). KTP is funded by Innovate UK along with other UK government funding organizations.

Yu-Chun Pan is with Business School, Oxford Brookes University, Oxford, United Kingdom (e-mail: ypan@brookes.ac.uk).

Chekfoung Tan is with Informatics Research Centre, Henley Business School, University of Reading, Reading, United Kingdom (e-mail: c.f.tan@pgr.reading.ac.uk). face difficult challenges in adapting their organizational structures, work processes and cost models [11], [12].

Law firms, as a type of KIBS organizations, utilize knowledge to create and deliver value to their customers. Therefore, knowledge management is a key enabler to achieve optimal performance for law firms. Existing researches have addressed the impact of the changing legal environment on knowledge management [5], legal and inter-disciplinary domain knowledge management [13], and sematic modelling in legal documents [14]. Effective knowledge management requires the dynamic capabilities within the knowledge domains [15], [16]. However, there is little literature on the dynamics and various dimensions in knowledge management in the legal sector and how the dynamic knowledge can be managed from a holistic perspective. Therefore, this paper reviews the literature on knowledge management in order to understand the dynamics and dimensions of knowledge and knowledge management in KIBS. Organizational semiotics [17] is then applied to further analyze the relationship between norms and knowledge management. Then through a case study in the UK legal sector, a three dimensional norm-based knowledge management framework is proposed in order to support the dynamic knowledge management in KIBS organizations.

\section{THEORETICAL BACKGROUND}

\section{A. Knowledge Management}

Knowledge is the subjective interpretation [18] and the behavioral use of information [19]. Knowledge can also be referred to as the awareness of what one knows through reasoning, experiencing, or learning; therefore, knowledge changes with the human experience [20]. Knowledge is the human processing of information and the know-how to perform tasks [21]. Knowledge management is the process of identifying, capturing, evaluating, processing, sharing and using an organization's information assets [22], [23]. The importance of knowledge management and its link with competitive advantages have been widely recognized [24].

In order to manage knowledge effectively, it is important to understand the dimensions of knowledge. One of the most common categorizing ways is to separate knowledge into explicit knowledge and tacit knowledge, based on whether the knowledge is formalized and codified or not [25]. Knowledge can also be categorized by the entities in which the knowledge is embedded. Embedded knowledge refers to the knowledge that is deeply rooted in rules, processes, products, culture, 
artifacts, people or structures [26], [27]. Knowledge can be embedded either formally or informally. Since embedded knowledge is always embedded in certain entities that provide the context for the knowledge, embedded knowledge can be considered context-based knowledge.

One of the key contextual dimensions of knowledge in KIBS is the specialist knowledge [28], which allows KIBS organizations to solve their customers' problems. An organization needs to coordinate and integrate the specialist knowledge of its members in order to achieve competitive advantages [29]. Customer knowledge is another important contextual dimension in creating competitive advantage and supporting long-term customer relationship management [16] Organizations need to effectively integrate the specialist knowledge with relevant customer knowledge to achieve competitive advantages.

\section{B. Organizational Semiotics}

Organizational semiotics is the study of organizations using concepts and methods of semiotics [17]. The concept of organizational semiotics is first introduced by Stamper [30] where the work is based on Peirce [31]'s work on semiotics. Semiotics is a doctrine of signs. Signs are formulated through a sign mediation process and it is known as semiosis [32]. Semiosis consists of three universal categories: firstness (sign, e.g. a presentation, an idea or a thing), secondness (object that carries the meaning of a sign) and thirdness (interpretant, e.g. interpretation of sign, action or feeling) [17]. Nake [33] adapts the concept of semiosis to further define data, information and knowledge (see Fig. 1). Organization is understood in terms of the signs and how human perform certain actions through norms; by all means, an organization is characterized as a structure of social norms from the organization semiotics perspective [34].

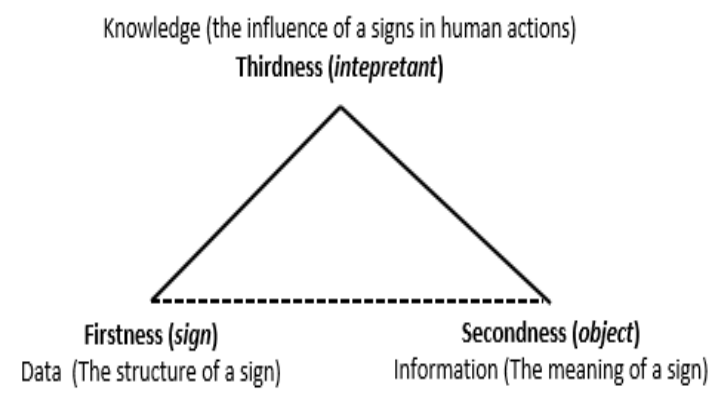

Fig. 1. The concept of semiosis (adapted from Nake [33]).

\section{Norms and Knowledge Management}

Norms can be regarded as knowledge in an organization [35]. Norms are developed through the practical experiences of the human agents in an organization [36]. Norms thus have a directive and prescriptive function [37]. The directive function guides the actions, whereas the prescriptive function looks at the existing norms in a situation and evaluates which is the best one for the course of action. In addition, Braf [38] also regards norms as a set of knowledge which concerns about the value standards for action and governs human behavior in an organization.

Stamper [39] proposes the organization onion (see Fig. 2) to analyze norms of an organization. Organization onion consists of three layers: informal, formal and technical. The informal layer refers to organizational culture, customs and values that are reflected as beliefs, habits and patterns of members within the organization. These norms are part of the culture in the organization so they are usually being applied informally. The formal layer denotes the rules and bureaucracy to perform the organizational activities. The technical layer automates the norms captured in the informal and formal layer. Since most rules and regulations in the business environment fall into the category of behavioral norms, the format of behavioral norm [40] is considered suitable for norm specifications that are used to record and describe norms. Norm specifications address norms via the format of whenever <condition> if <state> then<agent> is $<$ deontic operator $>$ to $\langle$ action $>$. Condition refers to the situation in which the responsible agent exists or roles that the agent plays. Condition corresponds with any circumstances that need to be met so that certain activities can be executed. Agent refers to who will execute the activities. The agent can be a human agent such as a person, a group or an organization or a non-human agent such as a software or physical artefact. Deontic operator elicits the categories of behavioral norms such as must - is obliged, may - is permitted and must not - is prohibited. Action specifies the activity to be performed based on the conditions

Drawing from the study of organizational morphology [41], each organization onion layer consists of substantive, communication and control norms [42]. Substantive activities are productivity related action. Communication activities administer actions such as informing relevant people about the relevant facts, work procedures, what action to be taken, when and by whom. Control activities reinforce the substantive and communication norms through rules and regulation. The concept in relating norms and knowledge has been adopted to derive the personalized clinical pathway for healthcare organizations [43].

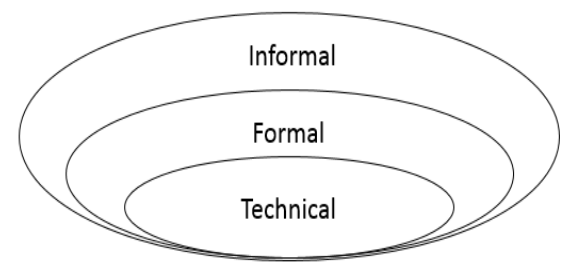

Fig. 2. The organization onion (Stamper [39]).

\section{RESEARCH METHOD}

This research is inspired by abductive reasoning research approach suggested by Kovács and Spens [44] via a case study based on participant observation and document review [45]. The case study has benefited from the principle that data collected through observation in a natural setting can provide a more accurate insight into organizations [46]. This research starts with the participant observation conducted by the first author of this paper together who works as an independent consultant since January 2014 with the case study organization and has been there for over a year, together with the researchers' prior theoretical knowledge on knowledge management. The result is to suggest the three dimensional norm-based knowledge management (3DNKM) framework. The advent of Legal Service Act 2007 has enabled the 
non-lawyers to enter the legal market, which has urged the law firms in the UK to innovate their value creation logics delivering value to their customers [11], [47]. This phenomenon highlights the need to establish a knowledge management framework so that law firms have the right knowledge when interacting with their clients. The selected organization is aware of the level of change in the legal market and hence being selected as the case study of this research. The case study organization is a UK Top 200 law firm that has over 250 employees and offers a wide range of legal services to business and individual customers. The fact that the case study organization operates from multiple sites amplifies its need to manage knowledge embedded in various parts of the organization. The finding of the case study is discussed in the following section.

\section{Proposed ThreE DimensionAl NORM-BASED KNOWLEDGE MANAGEMENT (3DNKM)}

Based on the theoretical background and the case study finding, this paper proposes the three dimensional norm-based knowledge management (3DNKM) framework, which aims to help KIBS organizations manage and integrate their knowledge embedded in different contexts. The 3DNKM framework consists of the contextual dimensions of knowledge and the relevant norms at all levels. This paper uses the case study law firm as an example to demonstrate how knowledge rooted in various contexts can be managed and integrated through 3DNKM framework.

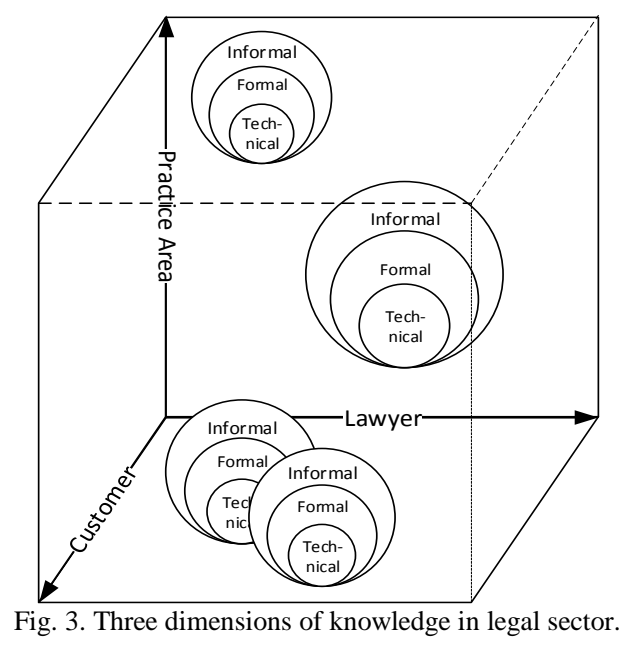

Derived from the case study, the contextual dimensions of knowledge in a law firm can be categorized into customer, practice area and lawyer. Customer knowledge refers to the understanding of customer, whether generic or specific. Generic customer knowledge can be demographics based understanding of customers. Specific customer knowledge refers to the knowledge about a specific customer, including a customer's communication preference, previous communication content, and previous matter information and so on. Practice area knowledge refers to legal knowledge, which can be broken down by the different legal practice areas, such as conveyancing, personal injuries, employment and family law. Each practice area is governed by the general regulations and some specialist area-based regulations. Lawyer knowledge refers to the individual lawyer's preferences and behaviors, which influence how legal matters are being dealt with. These three contextual dimensions provide the basic framework for identifying the relevant knowledge for each legal matter. Legal matters are dealt with by lawyers applying practice area knowledge to customers' problems in the way that suits the preferences and behaviors of both the lawyers and customers.

TABLE I: NORM CATEGORIES IN LEGAL SECTOR

\begin{tabular}{|c|c|c|c|}
\hline $\begin{array}{l}\text { Contextual } \\
\text { Dimension }\end{array}$ & $\begin{array}{l}\text { Meta-Level } \\
\text { Norms }\end{array}$ & $\begin{array}{l}\text { Macro-Level } \\
\text { Norms }\end{array}$ & $\begin{array}{l}\text { Micro-Level } \\
\text { Norms }\end{array}$ \\
\hline \multirow{10}{*}{ Customer } & \multirow{2}{*}{ Informal } & $\begin{array}{l}\text { Individual } \\
\text { preference }\end{array}$ & $\begin{array}{l}\text { Communication } \\
\text { preference }\end{array}$ \\
\hline & & $\begin{array}{l}\text { Demographics-based } \\
\text { preference }\end{array}$ & $\begin{array}{l}\text { Communication } \\
\text { preference }\end{array}$ \\
\hline & \multirow{4}{*}{ Formal } & \multirow{3}{*}{ Legal status } & Age-related \\
\hline & & & Gender-related \\
\hline & & & $\begin{array}{l}\text { Previous } \\
\text { matters }\end{array}$ \\
\hline & & Conflict of interest & Conflict check \\
\hline & \multirow{4}{*}{ Technical } & \multirow{3}{*}{ Legal status } & Age-related \\
\hline & & & Gender-related \\
\hline & & & $\begin{array}{l}\text { Previous } \\
\text { matters }\end{array}$ \\
\hline & & Conflict of interest & Conflict check \\
\hline \multirow{14}{*}{$\begin{array}{l}\text { Practice } \\
\text { area }\end{array}$} & \multirow[t]{2}{*}{ Informal } & Social custom & $\begin{array}{l}\text { Practice related } \\
\text { social norms } \\
\text { that can be } \\
\text { sensitive (e.g. } \\
\text { divorce, } \\
\text { probate and } \\
\text { etc.) }\end{array}$ \\
\hline & & $\begin{array}{l}\text { Organizational } \\
\text { domain }\end{array}$ & $\begin{array}{l}\text { Organizational } \\
\text { culture }\end{array}$ \\
\hline & \multirow{6}{*}{ Formal } & General practice & $\begin{array}{l}\text { SRA code of } \\
\text { conduct }\end{array}$ \\
\hline & & \multirow{4}{*}{ Specialist practice } & $\begin{array}{l}\text { SRA insolvency } \\
\text { practice rules }\end{array}$ \\
\hline & & & $\begin{array}{l}\text { SRA proper } \\
\text { selling rules }\end{array}$ \\
\hline & & & $\begin{array}{l}\text { SRA financial } \\
\text { services rules }\end{array}$ \\
\hline & & & $\begin{array}{l}\text { TLS quality } \\
\text { schemes }\end{array}$ \\
\hline & & $\begin{array}{l}\text { Organizational } \\
\text { domain }\end{array}$ & Internal policies \\
\hline & \multirow{6}{*}{ Technical } & General practice & $\begin{array}{l}\text { SRA code of } \\
\text { conduct }\end{array}$ \\
\hline & & \multirow{4}{*}{ Specialist practice } & $\begin{array}{l}\text { SRA insolvency } \\
\text { practice rules }\end{array}$ \\
\hline & & & $\begin{array}{l}\text { SRA proper } \\
\text { selling rules }\end{array}$ \\
\hline & & & $\begin{array}{l}\text { SRA financial } \\
\text { services rules }\end{array}$ \\
\hline & & & $\begin{array}{l}\text { TLS quality } \\
\text { schemes }\end{array}$ \\
\hline & & $\begin{array}{l}\text { Organizational } \\
\text { domain }\end{array}$ & Internal policies \\
\hline \multirow{5}{*}{ Lawyer } & Informal & $\begin{array}{l}\text { Individual } \\
\text { preference }\end{array}$ & $\begin{array}{l}\text { Communication } \\
\text { preference }\end{array}$ \\
\hline & \multirow[b]{2}{*}{ Formal } & \multirow[b]{2}{*}{$\begin{array}{l}\text { Roles, } \\
\text { responsibilities and } \\
\text { authorities }\end{array}$} & Write-off limits \\
\hline & & & $\begin{array}{l}\text { License (e.g. } \\
\text { insolvency } \\
\text { practitioner) }\end{array}$ \\
\hline & \multirow[b]{2}{*}{ Technical } & \multirow{2}{*}{$\begin{array}{l}\text { Roles, } \\
\text { responsibilities and } \\
\text { authorities }\end{array}$} & Write-off limits \\
\hline & & & $\begin{array}{l}\text { License (e.g. } \\
\text { insolvency } \\
\text { practitioner) }\end{array}$ \\
\hline
\end{tabular}


TABLE II: EXAMPLE SCENARIO

\begin{tabular}{|l|l|}
\hline Customer & $\begin{array}{l}\text { Mary: 55 years old female who lives in London } \\
\text { and works as a school teacher }\end{array}$ \\
\hline $\begin{array}{l}\text { Practice } \\
\text { area }\end{array}$ & $\begin{array}{l}\text { Residential conveyancing: Purchase of a leasehold } \\
\text { flat in London }\end{array}$ \\
\hline Lawyer & Tom: 60 years old solicitor \\
\hline
\end{tabular}

TABLE III: NORMS FOR EXAMPLE SCENARIO

\begin{tabular}{|c|c|c|c|}
\hline $\begin{array}{l}\text { Contextual } \\
\text { Dimension }\end{array}$ & Meta-Norms & Macro-Norms & Micro-Norms \\
\hline \multirow{3}{*}{ Customer } & Informal & $\begin{array}{l}\text { Individual } \\
\text { preference }\end{array}$ & $\begin{array}{l}\text { No email } \\
\text { Post only }\end{array}$ \\
\hline & Formal & Legal status & $\begin{array}{l}\text { Instructed previously } \\
\text { Identity checked }\end{array}$ \\
\hline & Technical & Legal status & $\begin{array}{l}\text { Instructed previously } \\
\text { Identity checked }\end{array}$ \\
\hline \multirow{5}{*}{$\begin{array}{l}\text { Practice } \\
\text { area }\end{array}$} & Informal & $\begin{array}{l}\text { Organizational } \\
\text { domain }\end{array}$ & $\begin{array}{l}\text { Congratulate on } \\
\text { purchase }\end{array}$ \\
\hline & \multirow[b]{2}{*}{ Formal } & General & SRA code of conduct \\
\hline & & $\begin{array}{l}\text { Specialist } \\
\text { practice }\end{array}$ & $\begin{array}{l}\text { TLS conveyancing } \\
\text { quality scheme }\end{array}$ \\
\hline & \multirow[b]{2}{*}{ Technical } & General & SRA code of conduct \\
\hline & & $\begin{array}{l}\text { Specialist } \\
\text { practice }\end{array}$ & $\begin{array}{l}\text { TLS conveyancing } \\
\text { quality scheme }\end{array}$ \\
\hline \multirow{3}{*}{ Lawyer } & Informal & $\begin{array}{l}\text { Individual } \\
\text { preference }\end{array}$ & $\begin{array}{l}\text { Communications by } \\
\text { post and through } \\
\text { secretaries }\end{array}$ \\
\hline & Formal & $\begin{array}{l}\text { Roles, } \\
\text { responsibilitie } \\
\mathrm{s} \text { and } \\
\text { authorities }\end{array}$ & $\begin{array}{l}\text { Head of department } \\
\text { Allow to open and } \\
\text { close matters } \\
\text { No WIP limits }\end{array}$ \\
\hline & Technical & $\begin{array}{l}\text { Roles, } \\
\text { responsibilitie } \\
\mathrm{s} \text { and } \\
\text { authorities }\end{array}$ & $\begin{array}{l}\text { Head of department } \\
\text { Allow to open and } \\
\text { close matters } \\
\text { No WIP limits }\end{array}$ \\
\hline
\end{tabular}

Fig. 3 shows the three contextual dimensions that construct the organizational onions with three layers of norms for legal matters. Each legal matter will be identified at a specific point in the three dimensional cube based on the index of practice area, customer and lawyer. Therefore, it requires the combination of practice area knowledge, customer knowledge and lawyer knowledge for law firms to manage its knowledge effectively to deliver value and create competitive advantages Each legal matter is governed and influenced by these three contexts that consist of informal, formal and technical norms. For each context, there are three levels of norms. The meta-level follows organizational semiotics and categories norms into informal, formal and technical. The macro level provides the categorization of the micro-norms, which are the specific norm instances. Table I provides the three levels of norms in customer, practice area and lawyer dimensions. The norms listed in the table are derived from the case study organization. It is noticeable that many of the formal and technical norms share the same norms. This is because technical norms often embedded in information systems, such as HR, CRM, practice management and finance systems, are often elicited from the formal norms. Technical norms enforce formal norms through machine-aided automation.

The details for each of the micro norm instance needs to be identified and recorded via norm specifications. For instance, whenever <the practice area is residential conveyancing $\rangle$, if $\langle$ the property is a leasehold property $\rangle$, then $\langle$ the lawyer $\rangle$ is $<$ obliged > to <check the length of the lease >. Once the norm specifications are captured, law firms can then collect the knowledge from the three contexts and integrate the knowledge for effective use. This paper uses a scenario from the case study organization to demonstrate how the 3DNKM framework supports knowledge management across three contextual dimensions. Table II describes the scenario where a customer (Mary) instructs a lawyer (Tom) to conduct a legal matter (residential conveyancing).

The three contexts then can be used to derive relevant informal, formal and technical norms. This paper constructs the relevant norms based on the sample scenario in all customer, practice area and lawyer contextual dimensions (see Table III). The collection of norms shows the knowledge required to enable the interaction between the three contexts.

The norm specifications of the identified norms can then be collated and managed, which allow organizations to apply knowledge management with a holistic view. The norm specifications of all related informal, formal and technical norms can guide people to perform tasks by applying the relevant knowledge.

\section{Discussions}

This paper echoes the importance of knowledge management in KIBS organizations. The norm perspective from organizational semiotics provides a different view into the categorization and management of embedded knowledge. Although many organizations attempt to implement best practice across the board via information systems, people find ways of workaround and local practices still exist [48], [49]. It is important to recognize these variables while managing knowledge across the organization. Therefore, in addition to customer and specialist knowledge, this paper introduces the contextual dimension of lawyer, who sometimes develop personalized practices. In other KIBS organizations, lawyers can be replaced by the agents who perform the substantive activities. Based on organizational semiotics and the case study finding, this paper proposes the 3DNKM framework, which consists of the three dimensional knowledge contexts (customer, practice area and lawyer) and the relevant norms.

The norms categories (see Table I) provide a basic guideline for identifying norms at all levels. This guideline can be applied and modified to suit different circumstances. In order to effectively manage the knowledge, conditions and states in the norm specifications related to informal factors, such as culture, religions and hobbits, need to be created. This will enable organizations to tailor communications based on customer knowledge to manage customer relationship. There might be conflicts between norms derived from different contexts. For example, there might be a mismatch in customer and lawyer's communication preference, e.g. the lawyer prefers posts when the customer prefers email. The control norms need to be established to deal with the conflicts of norms. The control norms could set specify who has the authority to make a decision in what kind of conflicts under what circumstances. The norms of decision making process for conflicts can then be built into information systems to support knowledge management automation.

This research asserts contributions from the theoretical, methodological and practical perspective. From the 
theoretical perspective, this research has extended the applied norms in the study of organizational semiotics to the field of knowledge management and propose the 3DNKM. The norm-based approach studies the knowledge embedded in the human system which is positioned at the informal and formal layer in the organization. Moreover, this approach shows how these embedded norms are facilitated in the technical layer. More important, this research has extended the application of norms to a three dimensional (customer, practice area and lawyer) analysis in the legal context.

By suggesting a way to analyze and capture the knowledge in an organization, this research has contributed methodologically. In addition, norm specification has been introduced the knowledge repository for an organization. The knowledge repository consists of rules which governs who can retrieve what knowledge. Lastly, this research has been conducted and demonstrated through a case study in a law firm. The practicality of 3DNKM has been postulated through the finding from the case study. By all means, 3DNKM enables law firms to efficiently managing knowledge in their organizations.

\section{CONCLUSION}

This paper has proposed a three dimensional norm-based knowledge management (3DNKM) framework for legal sector in the UK. Abductive reasoning is adopted for guiding the research process in this paper. The results have drawn contributions in the theoretical, methodological and practical perspective. The limitation of this research is that the 3DNKM framework is applied in a single organization. Therefore, as for the future work, more case studies will be conducted in the legal sector of the UK. The results collected will enable the researchers to compare and contrast the macro and micro norms in different law firms which will ultimately lead to a generalized knowledge management framework for the legal sector. In addition, a prototype for 3DNKM will be developed, which will include the norms for dealing with conflicts between informal, formal and technical norms derived from the three contextual dimensions. The prototype can potentially automate the knowledge management process and ensure the right knowledge is delivered at the right time to the right people.

\section{REFERENCES}

[1] Department of Trade and Industry, Our Competitive Future: Building the Knowledge Driven Economy, London, UK: Department of Trade and Industry, 1998.

[2] L. Bettencourt et al., "Client co-production in knowledge-intensive business services," Operations Management: A Strategic Approach, 2005, p. 273.

[3] B. Løwendahl, Strategic Management of Professional Service Firms, Copenhagen Business School Press DK, 2005.

[4] Y. Tsai, "Learning organizations, internal marketing, and organizational commitment in hospitals," BMC Health Services Research, vol. 14, no. 1, 2014, p. 152.

[5] T. Plessis and A. S. A. Toit, "Knowledge management and legal practice," International Journal of Information Management, vol. 26, no. 5, pp. 360-371, 2006.

[6] H. N. Butler and B. H. Kobayashi, "Unlocking the law: Building on the work of Larry E. Ribstein," International Review of Law and Economics, vol. 38, pp. 2-4, 2014.

[7] W. D. Henderson, "From big law to lean law," International Review of Law and Economics, vol. 38, pp. 5-16, 2014.
[8] L. E. Ribstein. (2010). The death of big law. [Online]. Available: http://works.bepress.com/ribstein/22

[9] R. E. Susskind, Tomorrow's Lawyers: An Introduction to Your Future, Oxford University Press Oxford, 2013.

[10] B. H. Barton, "A glass half full look at the changes in the American legal market," International Review of Law and Economics, vol. 38, pp. 29-42, 2014.

[11] P. Pleasence, N. J. Balmer, and R. Moorhead, A Time of Change: Solicitors' Firms in England and Wales, 2013.

[12] Royal Bank of Scotland, A Perspective on the Legal Market, 2014.

[13] A. Antonini et al., "Requirements of legal knowledge management systems to aid normative reasoning in specialist domains," New Frontiers in Artificial Intelligence, Springer, pp. 167-182, 2014.

[14] D. Jouve et al., "Conceptual framework for document semantic modelling: an application to document and knowledge management in the legal domain," Data \& Knowledge Engineering, vol. 46, no. 3, pp. 345-375, 2003.

[15] M. Alavi and D. E. Leidner, "Review: Knowledge management and knowledge management systems: Conceptual foundations and research issues," MIS Quarterly, pp. 107-136, 2001.

[16] P. Fidel, W. Schlesinger, and A. Cervera, "Collaborating to innovate: Effects on customer knowledge management and performance," Journal of Business Research, vol. 68, no. 7, pp. 1426-1428, 2015.

[17] K. Liu, Semiotics in Information System Engineering, Cambridge, UK: Cambridge University Press, 2000.

[18] F.J. Miller, I= 0-(Information has no intrinsic meaning), Information Research, vol. 8, no. 1, 2002.

[19] H.-J. Zimmermann, "Knowledge management, knowledge discovery, and dynamic intelligent data mining," Cybernetics and Systems: An International Journal, vol. 37, no. 6, pp. 509-531, 2006.

[20] C. McInerney, "Knowledge management and the dynamic nature of knowledge," Journal of the American Society for Information Science and Technology, vol. 53, no. 12, pp. 1009-1018, 2002.

[21] S. Wang and R. A. Noe, "Knowledge sharing: A review and directions for future research," Human Resource Management Review, vol. 20, no. 2, pp. 115-131, 2010.

[22] B. Duhon, "It's all in our heads," Inform, vol. 12, no. 8, pp. 8-13, 1998

[23] T. H. Davenport, "Saving IT's Soul: Human-centered information management," Harvard Business Review, vol. 72, no. 2, pp. 119-31, 1994.

[24] A. S. McCampbell, L. M. Clare, and S. H. Gitters, "Knowledge management: The new challenge for the 21st century," Journal of knowledge management, vol. 3, no. 3, pp. 172-179, 1999.

[25] J. S. Brown and P. Duguid, "Organizing knowledge," California Management Review, vol. 40, no. 3, p. 91, 1998.

[26] J. Badaracco, The Knowledge Link: How Firms Compete through Strategic Alliances, Harvard Business Press, 1991.

[27] P. R. Gamble and J. Blackwell, Knowledge Management: A State of the Art Guide, London: Kogan Page, 2001.

[28] J. Jordan and P. Jones, "Assessing your company's knowledge management style," Long Range Planning, vol. 30, no. 3, pp. 322-398, 1997.

[29] R. M. Grant, "Toward a knowledge-based theory of the firm," Strategic Management Journal, vol. 17, no. S2, pp. 109-122, 1996.

[30] R. Stamper, Information in Business and Administrative Systems, New York, USA: John Wiley \& Sons, Inc, 1973.

[31] C. S. Peirce, "Collected papers of charles sanders peirce: Pragmaticisms and pragnoaticism," Scientific Metaphysics, vol. 5-6, MA, US: Belknap Press, 1935.

[32] D. Nauta, The Meaning of Information, The Hague: Mouton, 1972.

[33] F. Nake, Data, Information, and Knowledge, Springer, pp. 41-50, 2002.

[34] R. Stamper et al., "Understanding the roles of signs and norms in organizations-a semiotic approach to information systems design," Behaviour \& Information Technology, vol. 19, no. 1, pp. 15-27, 2000.

[35] N. M. Ali and K. Liu, "A norm-based approach for profiling business knowledge," World Academy of Science, Engineering and Technology, vol. 66, pp. 1060-1064, 2010.

[36] R. Stamper and K. Liu, Collaborating through Shared Meanings, Social Norms and Distributed Authority, CTIT: Enschede, 1998.

[37] K. Liu et al., "Norm-based agency for designing collaborative information systems," Information Systems Journal, vol. 11, no. 3, pp. 229-247, 2001.

[38] E. Braf, "Knowledge or information: What makes the difference?" Organizational Semiotics: Evolving a Science of Information Systems, Kluwer Academic Publishers: Massachusetts, pp. 71-90, 2002.

[39] R. Stamper, Linguistic Instruments in Knowledge Engineering, RA Elsevier Science Inc., New York, NY, USA, 1992. 
[40] K. Liu and A. Dix, "Norm governed agents in CSCW," presented at 1st Int. Conference on Computational Semiotics, Paris, 1997.

[41] R. Stamper, K. Liu, and K. Huang. Organisational Morphology in Re-engineering, 1994.

[42] C. Tan, K. Liu, and E. White, "Information architecture for healthcare organizations: The case of a NHS hospital in UK," presented at Thirty Fourth International Conference on Information Systems (ICIS2013), Milan, Italy, 2013

[43] W. Li et al., "Normative modeling for personalized clinical pathway using organizational semiotics methods," presented at International Symposium in Computer Science and Computational Technology, IEEE, 2008.

[44] G. Kovács and K. M. Spens, "Abductive reasoning in logistics research," International Journal of Physical Distribution \& Logistics Management, vol. 35, no. 2, pp. 132-144, 2005.

[45] R. K. Yin, Case Study Research Design and Methods, Newbury Park, CA: Sage, 2003.

[46] P. N. Ghauri and K. Grønhaug, Research Methods in Business Studies: A Practical Guide, Pearson Education, 2005.

[47] Y.-C. Pan, P. Jackson, and D. Limburg, "Value creation logics: A UK case study," presented at 20th UK Academy for Information Systems Conference 2015 (UKAIS 2015), Oxford, UK, 2015.

[48] E. H. Ferneley and P. Sobreperez, "Resist, comply or workaround? An examination of different facets of user engagement with information systems," European Journal of Information Systems, vol. 15, no. 4, pp. 345-356, 2006

[49] J. Kingston, "High performance knowledge bases: Four approaches to knowledge acquisition, representation and reasoning for workaround planning," Expert Systems with Applications, vol. 21, no. 4, pp. $181-190,2001$

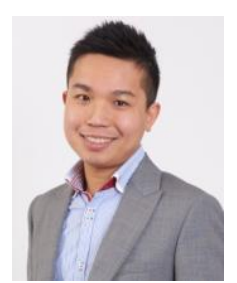

Yu-Chun Pan received a BA in advertising at National Chengchi University, Taiwan in 2004; an MSc in strategic supply chain management at Norwich Business School, University of East Anglia, United Kingdom in 2008; and a PhD in business informatics at Henley Business School, University of Reading, United Kingdom in 2014

$\mathrm{He}$ is currently a KTP (Knowledge Transfer
Partnership) Research Associate at Oxford Brookes University, United Kingdom. He is also a qualified PRINCE2 (PRojects IN Controlled Environments), MSP (Managing Successful Programmes), and P3O (Portfolio, Programme and Project Management Offices) Practitioner. He works closely with the industry to help organizations manage and benefit from IT-enabled change. His research interests include enterprise information systems, change management, knowledge management, and business process modeling.

Dr Pan is a member of the UK Academy of Information Systems (UKAIS) and the British Computer Society (BCS).

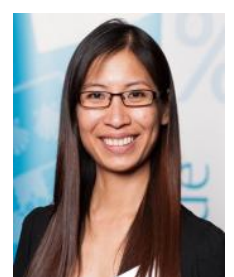

Chekfoung Tan was born in Malaysia on December 14, 1982. She graduated with first class honors in computer science degree at University Putra Malaysia, Malaysia in 2005; and distinction in the master of business informatics at University of Reading, United Kingdom in 2011. She is a final year $\mathrm{PhD}$ student in the Informatics Research Centre, Henley Business School, University of Reading in the United Kingdom. Her research area is in the development of information architecture for healthcare organizations, targeting on the UK hospitals. The PhD thesis has been submitted.

She has a few years' experiences working as a business analyst prior to commencing the $\mathrm{PhD}$ research. The IT projects she has been working in include the global service desk implementation for a cigarette manufacturing company, tills and stock system testing for a managed pub company and incident management for an oil and gas company in the United Kingdom. During her $\mathrm{PhD}$ years, she has published in a number of conferences which include the International Conference on Information Systems (ICIS) and the European Conference on Information Systems (ECIS). Her research interest is to expand the application of Organizational Semiotics in Information Systems Research.

Ms. Tan is a member of the Association for Information Systems (AIS). She was a finalist of the Three Minutes Competition of the PhD Conference organized by the Graduate School of the University of Reading in 2013. 